\title{
Controversy behind Applying EMI (English as the Medium of Instruction) among EFL Students
}

\author{
Anne Ratna S \\ Sekolah Tinggi Keguruandan Ilmu Pendidikan (STKIP) Garut, Garut, Indonesia \\ anners66@gmail.com
}

\begin{abstract}
This study attempts to figure out the factors which lead to the controversy towards applying the rule of English as the Medium of Instruction (henceforth EMI) among EFL students. The study also aims to investigate the perspectives of EFL freshmen and EFL lecturers towards applying EMI in EFL class. The researcher collected the data through questionnaire and interview towards 40 students from four different years and ten lecturers. Speaking class was chosen to be the sample where EMI was applied. The data, which were analyzed by using descriptive analysis, revealed that the factors which led to controversy towards the rule of EMI in EFL Speaking class were the benefits and the challenges of EMI. However, EMI program was also found to bring about the dilemma among students and lecturers who taught the subjects which required explanation in the mother tongue.
\end{abstract}

Keywords: Controversy, English as Medium Instruction (EMI), EFL speaking class

\section{INTRODUCTION}

The implementation of English as the only medium of instruction in EFL classroom setting has caused reactions among EFL students and EFL teachers. The reactions can be positive or negative. Therefore, this study is conducted to figure out the factors which lead to controversy towards the rule of applying only English as the medium of instruction (EMI) among EFL students. This study also attempts to investigate the perspectives of EFL freshmen and EFL lecturers towards applying the rule of using EMI in EFL class. This issue is necessary to investigate since it has been a dilemma for some teachers and practitioners in education to implement it due to the obstacles. Moreover, the number of research on the implementation of EMI in Indonesia is still limited, thus that this study is expected to fill in the gap. Furthermore, the scope of the study is delimited to the use of English as Medium Instruction (EMI) in speaking class of the freshmen students of the English Education Program at one private university in Garut.

\section{REVIEW OF RELATED LITERATURE}

English as Medium of Instruction (EMI) can be said as a visa to the global world. People can enter the competition in the global world and expand their career throughout the world by using English as Medium of Instruction (EMI). In spite of different native languages, people all over the world can communicate with each other. Therefore, English as international language can be considered as a key to open the gate of the global world.

In the educational field, EMI is discussed among applied linguists in relation to Content Language Integrated Learning (CLIL) which uses a foreign language to teach subjects or parts of subjects (Madhavan \& McDonald, 2014; Morell et al., 2014). However, the term EMI used in this study refers to "the teaching of a subject using the medium of the English language, but where there are no explicit language learning aims and where English is not the national language" (Madhavan \& McDonald, 2014). Therefore, EMI is different from CLIL which has "dual-focused aims, namely the learning of content and the simultaneous learning of a foreign language" (Marsh, 1994).

The benefit of EMI can be felt in the educational field. Morell et al. (2014) state that "the majority of lecturers affirmed that it was important for the academic and professional opportunities it created for students, followed by the fostering of international relations, especially for student and lecturer exchange programs." Meanwhile, Dearden (2014) states that English as Medium of Instruction (EMI) is considered by the policymakers as a way to internationalize their educational offer, to create opportunities for the students to join the global academy and the business community.

The results of prior research on the implementation of EMI in EFL countries showed the importance and the effectiveness of EMI (Chang, 2010; Kym \& Kym, 2014; Li \& Shum. 2008; Wong, 2010; and Wu, 2006). Regarding the importance of applying EMI, Kym \& Kym (2014) found that the mean of English importance for Korean students' current academic success was $3.18(\mathrm{SD}=0.97)$ and the mean of English importance for their future career success was 3.41 $(\mathrm{SD}=0.83)$. It might be inferred that Korean students regard English as more crucial for their future success than for their current performance. Kym \& Kym's (2014) finding was in line with the research conducted by Li \& Shum (2008) who stated that "it is important to provide students with adequate opportunities to learn the English language outside the class, as using English as the medium of instruction will only be useful for students with adequate English proficiency."

Meanwhile, regarding the effectiveness of EMI, $\mathrm{Wu}$ (2006), Wong (2010) and Chang (2010) found that EMI was effective to improve students' English proficiency. The result of research conducted by Wu (2006) showed that most students, even those who confessed that they did not have a good command of English, thought that EMI was an effective language policy. The findings also suggested that most students were aware that learning English by using EMI in the classroom was one of the most effective ways to improve their English.

Then, Wong (2010) found in his research that "not 
only did the class under the strict policy have a stronger preference for English as the sole medium of instruction, but their English proficiency had also become higher than that of the more Cantonese-tolerant class." The effectiveness of EMI is also proved by the research of Chang (2010) which also revealed that most of the Taiwanese students agreed that English instruction helped them to improve their English language proficiency, especially in terms of listening.

Apart from the effectiveness of EMI, the challenges of applying EMI were also found in the prior research reports. $\mathrm{Vu}$ \& Burns (2014) found four major challenges emerged when applying EMI such as lecturers' language abilities, students' language abilities and learning styles, pedagogical issues and resources. Meanwhile, Wu (2006) found that the Taiwanese students agreed that EMI had disadvantages such as making it difficult to understand the course content (82\%), stopping students from expressing themselves smoothly in class (86\%), and discouraging discussion and interaction between professors and students (54\%).

Since this present study focuses on EMI in speaking class, the challenges faced by students may be in line with the difficulty faced by students in speaking English. As Tuan and Mai (2015) highlight that the factors affecting students' speaking performance are such as performance conditions (time pressure, planning, standard of performance and amount of support), affective factors (such as motivation, confidence, and anxiety), listening ability, and feedback during speaking activities. Meanwhile, Ur (1996 in Al Hosni, 2014) mentions that the difficulty in speaking is caused by four factors such as inhibition, nothing to say, low or uneven participation, and mother-tongue use. In addition, the problems or difficulties in speaking English can also be influenced by learners' character and personalities (including inadequate frequency of speaking opportunities in the classroom), lack of sociocultural knowledge and lack of linguistic knowledge (Al Hosni, 2014; Al-Jamal \& Al-Jamal, 2014; Aleksandrzak, 2011; Azizifar et al, 2014; Bilal et al, 2013; Farooqui, 2007; Gan, 2012; Jamshidnejad, 2010; and Tuan \& Mai, 2015).

\section{METHODOLOGY}

The research method used in this study was a qualitative method. The study was conducted in one private university in Garut. The researcher firstly applied the rule of EMI in a speaking class to 120 freshmen students of English Education Program. Then, at the end of semester, 40 students out of 120 students were selected randomly to fill in the questionnaire about their perspectives after attending a speaking class with English as the only medium instruction (EMI). Meanwhile, 40 students from the first year until the fourth year were also taken randomly to be participants in the interview. Similarly, about ten lecturers of the English Education Program were also willing to be interviewed to deliver their perspectives.

Regarding instrumentation, the questionnaire administered to the sample consisted of 20 questions related to what happened and what students felt after getting the course. The questionnaire was the combination of close-ended and open-ended questionnaire. The respondents should choose to agree or disagree with the statements given along with the reasons why they chose to agree or disagree.

Meanwhile, there were 40 students consisted of 10 students from each level taken randomly from the first year until the fourth year to be interviewed. Then, ten lecturers were willing to be interviewed. They were asked to deliver their opinion about the use of English as the only medium of instruction among students of the English Education Program with leaving out the use of Bahasa Indonesia as the native language. After all data had been collected, the researcher analyzed the results of the study by using descriptive analysis.

\section{RESULTS AND DISCUSSION}

\subsection{Results of Questionnaire and Interview}

The result of interview in this study was used as the comparison towards the result of questionnaire to show that the data collected in this study were valid and reliable since all respondents involved in the questionnaire were not similar with those involved in the interview. The result of students' answers based on the interview is presented in the following figure:

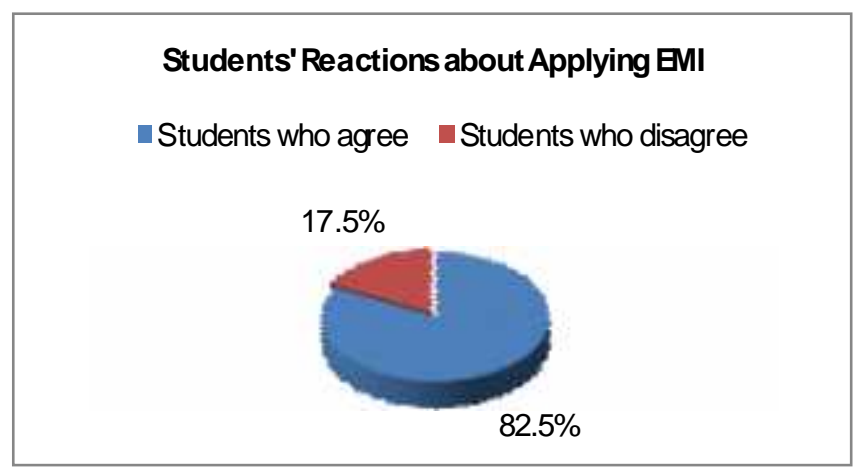

Figure 1. Students'Answers in the Interview 
Then, the result of lecturers' answer based on the interview is presented in the following figure:

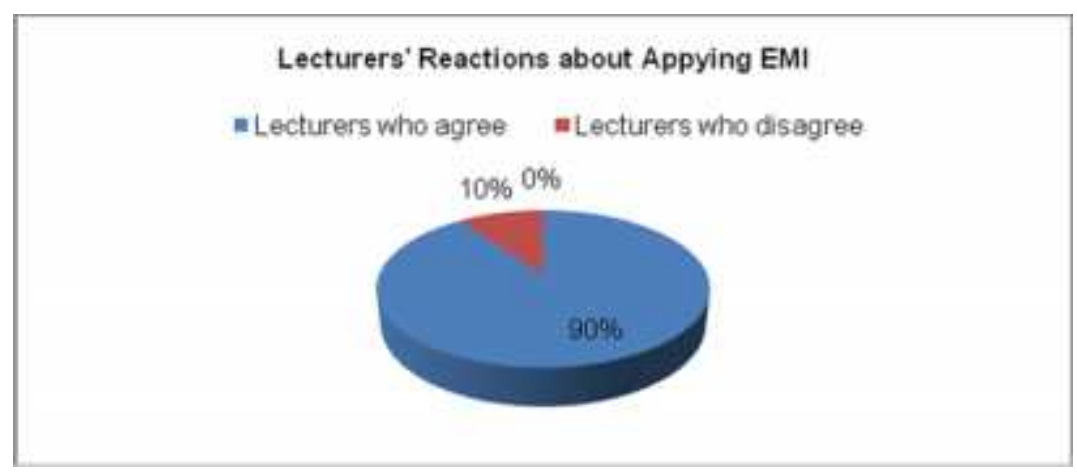

Figure 2. Lecturers' Answers in the Interview

Meanwhile, the result of questionnaire is presented in the following table:

Table 1. The Result of the Questionnaire

\begin{tabular}{|c|c|c|c|c|}
\hline \multirow[t]{2}{*}{ Statement } & \multicolumn{2}{|c|}{ Agree } & \multicolumn{2}{|c|}{ Disagree } \\
\hline & Total & $(\%)$ & Total & $(\%)$ \\
\hline I like it when getting Speaking class with EMI & 38 & 95 & 2 & 5 \\
\hline English indeed has to be used $100 \%$ completely in the classroom & 24 & 60 & 16 & 40 \\
\hline English should also be used outside classroom in the area of campus & 21 & 52.5 & 19 & 47.5 \\
\hline $\begin{array}{l}\text { Not only in the area of campus but students of English program should also speak English outside } \\
\text { campus }\end{array}$ & 15 & 37.5 & 25 & 62.5 \\
\hline $\begin{array}{l}\text { To communicate with the lecturers and other students of English program, there should be a rule } \\
\text { of allowing only English to use as medium instruction (EMI) }\end{array}$ & 21 & 52.5 & 15 & 47.5 \\
\hline After learning Speaking with EMI, I feel an increase in my speaking skill & 39 & 97.5 & 1 & 2.5 \\
\hline After learning Speaking with EMI, I get used to speaking English & 33 & 82.5 & 7 & 17.5 \\
\hline After learning Speaking with EMI, I feel more confident to speak & 35 & 87.5 & 5 & 12.5 \\
\hline After learning Speaking with EMI, I feel my vocabulary increased & 39 & 97.5 & 1 & 2.5 \\
\hline $\begin{array}{l}\text { After learning Speaking with EMI, I can understand what people say in English more easily than } \\
\text { before EMI was applied in the class }\end{array}$ & 32 & 80 & 8 & 20 \\
\hline Learning Speaking with EMI is very challenging to me & 40 & 100 & 0 & 0 \\
\hline I want to have the rule of EMI again next semester & 40 & 100 & 0 & 0 \\
\hline $\begin{array}{l}\text { In the next semester, I want the rule of EMI is occasionally applied, for example, once in two } \\
\text { weeks or once in a month }\end{array}$ & 26 & 65 & 14 & 35 \\
\hline $\begin{array}{l}\text { In the next semester, I want the rule of EMI is applied once in a week like what we have been } \\
\text { done }\end{array}$ & 35 & 87.5 & 5 & 12.5 \\
\hline The students of English Program indeed need to have EMI in the class & 40 & 100 & 0 & 0 \\
\hline It is better not to give punishment in applying the rule of EMI in the class & 2 & 5 & 38 & 95 \\
\hline I become motivated to speak English because I am afraid of the punishment & 17 & 42.5 & 23 & 57.5 \\
\hline The punishment is given in the class when the rule of EMI is applied me uncomfortable & 3 & 7.5 & 37 & 92.5 \\
\hline I am happy there is punishment in the class when applying the rule of EMI & 37 & 92.5 & 3 & 7.5 \\
\hline It is better to change the punishment with another punishment & 10 & 25 & 30 & 75 \\
\hline
\end{tabular}

\subsection{Discussion}

Based on the result of a questionnaire administered to the sample, more than $50 \%$ of respondents out of 40 freshmen students $(95 \%)$ stated that they like attending speaking class with English as the only medium instruction (EMI). This result was supported by the result of interview towards 40 students from different semesters and ten lecturers who also more than $50 \%$ agreed with the implementation of EMI among students of English Program $(82.5 \%$ and $90 \%$ respectively). The respondents assumed that EMI gave the students more opportunity to practice speaking English. One of the respondents in the interview said: 
be fluent in speaking English. One of the lecturers said: class, it would be a good idea. We can practice English every day so we can speak English well, I think."

Then, more than $50 \%$ of respondents chose to agree with using English inside and outside the classroom. In addition, all respondents (100\%) agreed that EMI (English Day) was necessary to conduct and wished to have it again next semester. However, only $37.5 \%$ of respondents who agreed with using English outside campus. This means that most students of English Program supported the use of English in the area of campus not at home because they thought that not many people would understand English.

The findings above are in line with the results of the study conducted by Berger (2011), Chang (2010) and Wu (2006) which also showed that students prefer the use of English only and want the instructor to use English only. As Berger (2011) states, ".... shown in Figure 2, it was found that the majority of students want the instructor to use only English."

Similar to the prior research which found that EMI is considered to be "discouraging discussion and interaction between professors and students (Wu, 2006)", most respondents in the present study $(52.5 \%)$ disagreed if EMI was used for communication between lecturers and students because of limited vocabulary. The reasons stated by the respondents in the questionnaire were similar to what other respondents indicated in the interview that they felt it was too difficult for the students to speak EMI without involving Bahasa Indonesia at all because English was not their mother tongue. One of the students said:

\begin{abstract}
"I.....eum....don't agree with this because we.. Our mother tongue is Sudanese and..and we change our language to English. And you know it seems difficult to make the English as the common language. So I don't agree with this because we still learning about English...."
\end{abstract}

Related to the benefits of EMI program which made the respondents agreed with the rule of applying EMI in the EFL class, most respondents $(97.5 \%)$ felt their speaking skill increased after attending the course. Other benefits were the respondents became accustomed to speaking English (82.5\%), more confident to speak English (87.5\%), had an increase in vocabulary mastery $(97.5 \%)$, and understood what others said in English more easily than before this program was implemented $(80 \%)$. One of the respondents in the interview said,

\section{"I believe that this program can make students develop their Speaking skill."}

Similarly, the lecturers in the interview also said that the program was very beneficial that the students could get benefit from listening to the lecturers' speaking and imitating how to speak English well. They also said that it would push the students to learn English faster and it was a must for the students of English Program to practice speaking in order to

\begin{abstract}
"English is foreign language, and in this context, the students are learning English for speaking skill it will push students' competence in expressing their ideas in foreign language so I do believe that practice, practice, and practice make perfect."
\end{abstract}

The findings about the benefits of EMI program above are in line with the findings of research conducted by Chang (2010), Wong (2010) and Wu (2006) which also revealed that EMI was considered beneficial in improving students' English proficiency. However, what makes the findings of the present study different to the prior research lies in the students' English skill found to be improved with the help of EMI program. In Chang's research (2010), EMI was found to be helpful in improving students' listening skill; meanwhile, in the present study, EMI was found to be helpful in improving students' speaking skill.

On the contrary, according to the result of the interview, the EMI program had also provided challenges to the students. Most respondents said that the difficulty of implementing this program was because English was not their mother tongue. This response is in line with one of the factors which caused difficulty in speaking as mentioned by Ur (1996 in Al Hosni, 2014), i.e., mother tongue factor. The respondents of the present study also assumed that the students who had limited vocabulary would get difficulty to understand the learning material if the lecturer explained using English without mixing the language with Bahasa Indonesia. Lastly, the culture factor was made as an excuse against this program. One of the respondents said:

\begin{abstract}
"... if we use English, our culture in Sundanese and Indonesian will extinct, and we'll become like you know.. What.. It will make the next generation or another next year because it will lose identity as a nation."
\end{abstract}

Finally, using punishment to motivate students to use EMI in the class unexpectedly encouraged a good response from the students. About $95 \%$ of questionnaire respondents disagreed if the punishment was abolished. However, $42.5 \%$ of questionnaire respondents admitted that they are motivated to speak English because of being afraid of the punishment. A solution on how to encourage students to speak eagerly without any punishments need to be sought.

\section{CONCLUSION}

The controversy behind applying the rule of using English as the Medium of Instruction (EMI) was influenced by the benefits and the challenges of the implementation of EMI. The benefits are such as EMI can enhance EFL students' speaking skill, enrich EFL students vocabulary, give EFL students opportunity to practice speaking English, make EFL students accustomed to speaking English, build students' selfconfidence to speak English, and make EFL students understand more easily what people say in English than before the EMI program was implemented. 
However, the rejection towards the implementation of EMI was derived from the challenges the students felt when attending speaking class with EMI. The challenges can be caused by three factors, i.e., the habit of speaking English factor, vocabulary factor, and traditional culture and mother tongue-oriented factor. First, the habit of speaking English factor means that the students who do not have a habit of speaking English before will feel shy and not confident to speak English which leads to the rejection towards EMI. Feeling shy belongs to inhibition factor which can cause difficulty in speaking. Ur (1996 in Al Hosni, 2014) states, "many factors cause difficulty in speaking, and they are as follows: 1. Inhibition. Students are worried about making mistakes, fearful of criticism, or simply shy...".

Second, vocabulary factor means the EFL students get difficulty to understand what others say in English because of limited vocabulary. This limitation of vocabulary may lead to nothing to say a situation where "students have no motive to express themselves" (Ur, 1996 in Al Hosni, 2014). This factor may also challenge not only students' speaking skill, but also students' listening skill.

Third, traditional culture and mother tongue-oriented factor means that some students are afraid of losing the patriotic spirit and traditional culture because of speaking English every day. This may result from having an abundant sense of belonging towards their traditional culture. This may also result from lack practicing to speak English that leads to culture shock when being offered the rule of EMI. Moreover, "learners who share the same mother tongue tend to use it because it is easier and because learners feel less exposed if they are speaking their mother tongue" (Ur, 1996 in Al Hosni, 2014).

To overcome the challenges above, giving reward and punishment can motivate the students to be willing to involve in EMI program. As stated by Ilegbusi (2013) that "It is perhaps correct to infer from the evidence that many students tend to be motivated to do any work at all this way." However, reward gives stronger effect than punishment to motivate students in learning (see Kohn, 1994; Ching, 2012). Therefore, it is necessary to balance giving reward and punishment.

\section{ACKNOWLEDGMENT}

I would like to say a big thank you to Dr. H. Nizar Alam Hamdani, MM, MT, M.Si (Executive Director of STKIP Garut), Dr. H. Abdul Hasim, M.Pd. (Assistant Director I of STKIP Garut), Dr. H. Asep Nurjamin, M.Pd. (Assistant Director II of STKIP Garut), Dr. H. Endang Dimyati, M.Pd. (Assistant Director III of STKIP Garut), and Dr. H. Yoyo Surjakusumah, M.Pd. (Head of English Education Program) for all their help. Special thanks are also given to H. Suparno (Executive Director of Griya Winaya Foundation), H. Rostina Sundayana, M.Pd. (Executive Director of AMIK Garut), the lecturers and the students of English Education Program, and all people for their support for this research.

\section{REFERENCES}

Aleksandrzak, M. (2011). Problems and challenges in teaching and learning speaking at advanced level. Poznan: Adam Mickiewicz University Press Poznan.

Al Hosni, S. (2014). Speaking difficulties encountered by young EFL learners. International Journal on Studies in English Language and Literature (IJSELL), 2(6), 22-30.

Al-Jamal, D. A., \& Al-Jamal, G. A. (2014). An investigation of the difficulties faced by EFL undergraduates in speaking skills. English Language Teaching, 7(1). doi:10.5539/elt.v7n1p19.

Azizifar, A., Ghaitasi, H., \& Gowhary, H. (2014). EFL Adult learner's attitudes towards learning speaking. International Research Journal of Applied and Basic Sciences, 8(10), 1755-1764.

Berger, M. (2011). English-only policy for all? Case of a university English class in Japan. Polyglossia, 3, 27-43.

Bilal, H. A., Rehman, A., Rashid, A., Adnan, R., \& Abbas, M. (2013). Problems in speaking English with L2 learners of rural area schools of Pakistan. European Journal of Humanities and Social Sciences, 24(1), 1220-1235.

Chang, Y. Y. (2010). English-medium instruction for subject courses in tertiary education: Reactions from Taiwanese undergraduate students. Taiwan International ESP Journal, 2(1), 55-84.

Ching, G. S. (2012). Looking into the issues of rewards and punishment in students. International Journal of Research Studies and Psychology, 1(2), 29-38.

Dearden, J. (2014). English as a medium of instruction - a growing global phenomenon: Phase 1. UK: British Council.

Farooqui, S. (2007). Developing speaking skills of adult learners in private universities in Bangladesh: problems and solutions. Australian Journal of Adult Learning, 47(1), 94-110.

Gan, Z. (2012). Understanding L2 speaking problems: Implications for ESL curriculum development in a teacher training institution in Hongkong. Australian Journal of Teacher Education, 37(1), doi:10.14221/ajte.2012v37n1.4.

Jamshidnejad, A. (2010). The construction of oral problems in an efl context: An innovative approach. Studies in Literature and Language, 1(6), 8-22.

Ilegbusi, M. I. (2013). An analysis of the role of rewards and punishment in motivating school learning. Computing, Information Systems \& Development Informatics, 4(1).

Kohn, A. (1994). The risks of rewards. Retrieved from http://www.alfiekohn.org/teaching/ror.htm.

Kym, I., \& Kym, M. H. (2014). Students' perceptions of EMI in higher education in Korea. The Journal of Asia TEFL, 11(2), 35-61.

Li, B., \& Shum, A. O. N. (2008). A discussion on using English as medium of instruction in Hong Kong and the sociolinguistic impacts. LCOM Papers 1, 37-51.

Madhavan, D., \& McDonald, J. (2014, June 16th). Webinar: English as Medium of Instruction (EMI): Philosophies and policies. Retrieved from 
www.oecd.org/edu/imhe/foodforthoughtenglishasamedi umofinstructionwebinar.pdf

Marsh, D. et al. (1994). Language teacher training and billingual education in findland. Retrieved from www.celelc.org/projects/Past_Projects/TNP_Languages/ TNP1_resources/SP6NatRepFI.pdf?1372922388

Morell, T et al. (2014). English as the medium of instruction: A response to internationalization. Retrieved from https://web.ua.es/va/ice/jornadas-redes-

2014/documentos/comunicacions-posters/tema5/392287.pdf

Tuan, N. H., \& Mai, T. N. (2015). Factors affecting students' performance at Le Thanh Hien high school. Asian Journal of Educational Research, 3(2), 8-23.

Vu, N. T. T., \& Burns, A. (2014). English as a medium of instruction: Challenges for Vietnamese tertiary lecturers. The Journal of Asia TEFL, 11(3), 1-31.

Wong, R. M. H. (2010). The effectiveness of using English as the sole medium of instruction in English classes: student responses and improved English proficiency. Porta Linguarium 13, 119-130.

Wu, Wen-Shuenn. (2006). Students' attitudes toward EMI: Using Chung Hua University as an example. Journal of Education and Foreign Language and Literature, 4, 6784. 